\title{
Prediction of energy cropping trends in some EU countries
}

\author{
Anett LÁSZLÓK ${ }^{1}$ - István TAKÁCS ${ }^{2}$ \\ 1: Szent István University, 2103 Gödöllö, Páter Károly str. 1.; E-mail: laszlok.anett@gmail.com \\ 2: Óbuda University, 1084 Budapest; Tavaszmező str. 15-17.; E-mail: takacs.istvan@kgk.uni-obuda.hu
}

Keywords: alternative energy sources, biofuel, mathematical model, logistic function

\section{Introduction}

The governments of the member countries of the European Union committed to decrease the greenhouse gas emission assumed to increase the alternative energy source cropping on lands, which rises the competition for this resource between the food or feed and the energy plants. There are different forecasts about the food price changes (e.g. according to Collins (2008) or Mitchell (2008) rising, but according to Popp - Potori (2008), Baffes - Haniotis (2010) or Popp et al. (2010)) there is not significant effect because of the rise of the share of the alternative energy cropping in land use. According to the statistics, the characteristics of the growth of the energy cropping were different during the last decade in the member countries. The research aim was to identify the parameters of the trends by non-linear regression model. Based on the results of Járási [2009] one of the most acceptable method for estimation of the future alternative energy production is the logistic function because of the general experience of ,the trees do not grow until the sky”.

\section{Materials and methods}

During the research the timeline series of biofuel production from 2004 to 2015 of the EUROSTAT database was used. Seven countries of the EU were analysed by the model, and that countries were the first six countries with highest biofuel production in the EU (i.e. Germany, Spain, France, Italy, the Netherlands, Sweden) and the seventh was Hungary for a positioning and a comparison. For timeline analysis the Verhulst-type logistic function modified by Hunyadi (2004) (see Járási, 2009. 5. p.). was used with a further modification by introducing a $\Delta \mathrm{t}$. The formula is the following:

$$
y_{t}=\frac{k}{1+\exp \left[\beta_{0}+\beta_{1} \cdot\left(t_{i}-\Delta t\right)\right]}
$$

where $\mathrm{k}$ is the impregnation parameter (saturation level); $\beta_{0}$ is shifting parameter, when everything is constant it shifts the curve to the right; $\beta_{1}$ is shape parameter, its growth makes the function steeper (in absolute value); $\mathrm{t}_{\mathrm{i}}$ is an element of the timeline and $\Delta \mathrm{t}$ is time lagging. The parameters of the functions were estimated by heuristic method with stepwise refinement.

\section{Results and discussion}

The estimated parameters of the logistic functions for prediction of biofuel production are presented in Table 1. The correlation coefficients suggest that most of the estimation of parameters results strong correlation between the timelines and the value of predictor functions. By replacement of the parameters into the logistic function it could be explored that in case of Germany, France and Sweden the production is close to its predicted 
maximum (see relative change of the predicted biofuel production from 2014 to 2015). In the other analyzed countries the growth of the biofuel production decreases.

Table 1 Parameters of the predictions by logistic functions for forecast the biofuel production in some EU countries

\begin{tabular}{|l|c|c|c|c|c|c|}
\hline \multicolumn{1}{|c|}{ Country } & $\mathrm{k}$ (in ktoe) & $\beta_{0}$ & $\beta_{1}$ & $\Delta \mathrm{t}$ (in year) & $\mathrm{r}^{2}$ & $\begin{array}{c}\text { Relative change from } \\
\text { 2014 to 2015 (in \%) }\end{array}$ \\
\hline Germany & 3400 & -1.5 & 1.0587 & 5.0 & 0.9460 & 0.00 \\
\hline Spain & 1200 & -0.6 & 1.0202 & 2.0 & 0.8956 & 0.68 \\
\hline France & 2500 & -0.9 & 1.0618 & 3.5 & 0.9737 & 0.03 \\
\hline Italy & 900 & -0.6 & 1.0202 & 2.0 & 0.7240 & 0.68 \\
\hline the Netherlands & 1500 & -1.2 & 2.7183 & 0.0 & 0.9744 & 0.47 \\
\hline Sweden & 350 & -0.6 & 1.0513 & 5.0 & 0.7323 & 0.12 \\
\hline Hungary & 400 & -0.6 & 1.0100 & 0.0 & 0.9537 & 2.21 \\
\hline
\end{tabular}

ktoe $=$ kilotonne of oil equivalent

\section{Conclusions}

The energy cropping (i.e. biofuel production) is mainly a political issue because of its environmental, energy policy and agro-policy aspects. Different reasons drive the decisions about rising the production and utilization of the biofuels in the different countries. The predictions suggest that the first generation of biofuel production will not grow considerable in the European Union yet. This conclusion is confirmed by the directive of the Council of the European Union in 2017, which limits the share of the first generation of biofuel production in $7 \%$, at the same time it inspires for the production of biofuel production by developed technologies because of the reduction the direct changes in the land use.

\section{References}

Baffes, J. - Haniotis, T. (2010): Placing the 2006/2008 Commodity Price Boom into Perspective, World Bank Policy Research Working Paper, no. 5371, 42 p. https://doi.org/10.1596/1813-9450-5371

Collins, K. J. (2008): The role of biofuels and other factors in increasing farm and food prices, A Review of Recent Developments with a Focus on Feed Grain Markets and Market Prospects, Supporting material for a review conducted by Kraft Foods Global, Inc., 34 p.

Hunyadi L. (2004): A logisztikus függvény és a logisztikus eloszlás, Statisztikai Szemle 82. (10-11): 991-1011.

Járási, É. Zs. (2009): Economic opportunity and condition of growth of the organic agriculture in the European Union. Doctoral (Ph.D.) thesis. Szent István University. Gödöllö. 30 p. Online: https://szie.hu/file/tti/ archivum/Jarasi_Eva_PhD_Thesis_English_KESZ.pdf. Download: 22.12.2018.

Mitchell, D. (2008): A Note on Rising Food Prices, World Bank Policy Research Working Paper, no. 4682, 21.

Popp J., Potori N. (2008): Az élelmezés-, energia- és környezetbiztonság összefüggései, Gazdálkodás, 52. (6): 528-544.

Popp J., Somogyi A., Bíró T. (2010): Újabb feszültség a láthatáron az élelmiszer- és bioüzemanyag-ipar között?, Gazdálkodás, 54. (6): 592-603. 